\title{
PENGARUH PENERAPAN MODEL PEMBELAJARAN SAINS TEKNOLOGI MASYARAKAT (STM) TERHADAP KETERAMPILAN BERPIKIR KRITIS DAN PRESTASI BELAJAR IPS DI SMP NEGERI 1 PENEBEL
}

\author{
Ini Gusti Ayu Made Sri Evariani ${ }^{1}$, I Wayan Kertih ${ }^{2}$, lyus Akhmad Haris ${ }^{3}$ \\ Program Studi Pendidikan IPS, Program Pascasarjana \\ Universitas Pendidikan Ganesha \\ Singaraja, Indonesia
}

e-mail: evariani917@yahoo.com ${ }^{1}$

\begin{abstract}
Abstrak
Penelitian ini bertujuan untuk mengetahui pengaruh model pembelajaran sains teknologi masyarakat (STM) terhadap prestasi belajar dan kemampuan berpikir kritis siswa kelas IX SMP Negeri 1 Penebel. Populasi dalam penelitian ini adalah seluruh siswa kelas IX SMP Negeri 1 Penebel tahun pelajaran 2017/2018 berjumlah 249 orang yang tersebar di delapan kelas. Dengan ramdom sampling, kelas $I X_{B}$ terpilih sebagai kelas eksperimen dan kelas $I X_{A}$ sebagai kelas kontrol dengan jumlah masing-masing sampel 32 dan 30 orang. Data dikumpulkan dengan tes essay untuk keterampilan berpikir kritis dan tes pilihan ganda untuk mengukur prestasi belajar siswa. Data dianalisis dengan anava dan manova satu jalur dengan uji F. Hasil penelitian menunjukkan bahwa: (1) terdapat perbedaan prestasi belajar siswa antara yang mengikuti pembelajaran dengan model STM dan pembelaaran konvensional dengan $F_{\text {hitung }}=84,437(p=0,000<0,05)$, (2) terdapat perbedaan kemampuan berpikir kritis siswa antara yang mengikuti pembelajaran dengan model STM dan konvensional dengan $F_{\text {hitung }}=50,209(p=0,000<0,05)$, (3) terdapat perbedaan prestasi belajar dan kemampuan berpikir kritis antara yang mengikuti pembelajaran dengan model STM dan konvensional dengan F- Wilks' Lambda $=43,569(p=0,000<0,05)$. Berdasarkan hasil tersebut dapat disimpulkan bahwa model pembelajaran STM dan model pembelajaran konvensional berpengaruh secara signifikan terhadap prestasi belajar dan kemampuan berpikir kritis siswa kelas IX SMP Negeri 1 Penebel baik secara terpisah maupun simultan. Untuk itu model pembelajaran STM dapat dijadikan salah satu alternatif dalam pembelajaran IPS di SMP
\end{abstract}

Kata kunci: model pembelajaran STM, pembelajaran konvensional, prestasi belajar, kemampuan berpikir kritis

\begin{abstract}
The aim of this study is to know The Influence of Application Science Technology Community (STM) learning model to critical thinking skill and students learning achievement in Sosial Science at SMP Negeri 1 Penebel. The population of this study is all of the year IX students of SMP Negeri 1 Penebel in 2017/2018 period. There are 249 students in eight of classes. By sampling randomly, the students in year IXB was selected as the experiment class and year IXA was selected as the class control which is consist of 32 samples and 30 samples of students. The data was collected by test. Then, the data was analysed by "Anava and Manova" one way with $\mathrm{F}$ test. The results of the study are : (1) there is difference of students achievement of the students that study with STM Learning Model from the students that study with conventional learning model by result $F_{\text {hitung }}=84,437(p=0,000<$
\end{abstract}


$0,05),(2)$ there is difference of critical thinking skill of the students that study with STM Learning Model from the students that study with conventional learning model by result $F_{\text {hitung }}=50,209(p=0,000<0,05)$, (3) there is difference students achievement and critical thinking skill of the students that study with STM learning model from the students that study with conventional learning model by result $\mathrm{F}$ Wilks' Lambda $=43,569(p=0,000<0,05)$.

Based on the result of the study can be conclude that STM Learning Model and conventional learning model have influence significantly to the students achievement and critical thinking skill of the students year IX at SMP Negeri 1 Penebel in separately or simultaneously. Thus, STM Learning Model can be the one of alternative learning model for Social Science in SMP.

Keywords: STM Learning Model, Conventional Learning, Learning Achievement, Critical Thinking Skil

\section{PENDAHULUAN}

Secara makro pengembangan pendidikan pada Abad ke 21 harus dilaksanakan dengan berstandar pada empat pilar pendidikan sebagaimana yang telah direkomendasikan oleh UNESCO ( Hartono dalam Nita Tristina, 2011:21) yaitu learning to know, learning to do, learning to be dan learning to live together.Konsep pendidikan yang dicanangkan dan direkomendasikan oleh UNESCO ini dilatar belakangi oleh berbagai krisis multidimensional terutama yang menyangkut keharmonisan sosial yang dihadapi penduduk dunia termasuk Indonesia, dimana manusia cenderung individualis, ingin mencapai tujuan secara instant dan rendahnya semangat belajar dalam meraih prestasi.

Persoalan tersebut tidak terlepas dari ketidakberhasilan pendidikan IPS yang berfungsi mentransmisikan pengetahuan dan pemahaman tentang masyarakat berupa fakta-fakta dan ide-ide kepada anak. Selain itu juga mengembangkan rasa kontinuitas dan stabilitas, memberikan informasi dan keterampilan sosial sehingga mereka dapat ikut memajukan masyarakat sekitarnya.

Berdasarkan Peraturan Menteri Pendidikan Nasional (Permendiknas) Nomor 22 Tahun 2006, pembelajaran IPS mempunyai beberapa tujuan diantaranya : mengenalkan konsep yang berkaitan dengan kehidupan masyarakat dan lingkungannya, memiliki kemampuan dasar untuk berpikir logis dan kritis, rasa ingin tahu, inkuiri, memecahkan masalah dan keterampilan dalam kehidupan sosial, memiliki komitmen dan kesadaran terhadap nilai - nilai sosial dan kemanusiaan serta memiliki kemampuan berkomunikasi, bekerja sama dan berkompetisi dalam masyarakat yang majemuk ditingkat lokal, nasional dan global. Selama ini fokus guru - guru hanya sebatas pada pengenalan konsep masyarakat dan sosial (tujuan pertama). Tujuan yang lain, pengembangan kemampuan dasar berpikir logis dan kritis, pengembangan komitmen dan kesadaran nilai-nilai sosial, serta pengembangan kemampuan berkomunikasi, bekerja sama dan sebagainya hanya sepintas lalu saja. Artinya, belum ada hubungan anatara ranah yang tertuang dalam ranah yang menjadi ciri- ciri kompetensi inti dan kompetensi dasar.

Dilihat dari tujuan yang dinyatakan dalam permendiknas di atas siswa yang belajar IPS dituntut untuk mampu berpikir kritis, karena persoalan persoalan sosial yang dihadapi siswa pada saat ini maupun masa depan perlu dikritisi secara arif dan mempertimbangkan berbagai dimensi sosial. Di samping itu pembelajaran IPS khususnya di SMP begitu unik karena harus mendidik dan mempersiapkan para murid meningkatkan kemampuan, pengetahuan dan keterampilan sosial dalam membuat keputusan-keputusan rasional sebagai warga negara yang secara kultural memiliki keragaman, dan yang hidup dalam masyarakat demokratis di dunia yang saling ketergantungan.

Metode yang dianggap cocok dengan karakteristik pendidikan IPS, tujuan dan perkembangan perubahan sosial yang terjadi saat ini adalah Pendekatan Sains 
Teknologi dan Masyarakat (STM) dalam pandangan ilmu-ilmu sosial dan humaniora, pada dasarnya memberikan pemahaman tentang kaitan antara sains, teknologi (rekayasa sosial ) dan , melatih kepekaan penilaian peserta didik terhadap dampak lingkungan sebagai akibat perkembangan sains dan teknologi. Menurut Raja (2009), keputusan yang dibuat oleh masyarakat biasanya memerlukan penggunaan teknologi untuk melaksanakannya, bahkan, masyarakat dan ilmu pengetahuan menggunakan teknologi sebagai sarana untuk menyimpan informasi. Dengan demikian peranan penting yang dimiliki oleh teknologi dapat berfungsi sebagai sarana tindakan dan penyidikan dalam pendekatan STM.

Pendidikan sains pada hakikatnya merupakan upaya pemahaman, penyadaran, dan pengembangan nilai positif tentang hakikat sains melalui pembelajaran. Sains pada hakikatnya merupakan ilmu dan pengetahuan tentang fenomena alam yang meliputi produk dan proses. Pendidikan sains merupakan salah satu aspek pendidikan yang menggunakan sains sebagai alat untuk mencapai tujuan pendidikan nasional secara umum dan tujuan pendidikan sains secara khusus, yaitu untuk meningkatkan pengertian terhadap dunia alamiah (Amien, 1992 dalam Widyatiningtyas, 2009).

Pada domain learning to know siswa belajar yang penting sesuai dengan jenjang pendidikan yang diikuti. Pada konteks learning to do siswa mengembangkan keterampilan dengan memadukan pengetahuan yang dikuasai dengan latihan (law of practice), sehingga terbentuk keterampilan yang membantu siswa untuk dapat menyesuaikan diri dengan standar harapan masyarakat dalam norma-norma yang berlaku di sekelilingnya serta agar siswa dapat memelihara hubungan sosial secara positif dengan keluarga, teman sebaya, masyarakat dan pergaulan dilingkungan yang lebih luas. Learning to be, siswa belajar secara bertahap menjadi individu yang utuh memahami arti hidup dan tahu apa yang terbaik dan sebaliknya dilakukan, agar dapat hidup dengan baik.
Learning to live together, siswa dapat memahami arti hidup dengan orang lain dengan jalan saling menghormati, menghargai, serta memahami tentang adanya saling ketergantungan (Hartono dalam Nita Tristina, 2011:21).

Model STM dalam pembelajaran IPS merupakan salah satu model baik secara teoritis maupun empiris dapat meningkatkan mutu dan kualitas pembelajaran IPS. Winaya (2009) mengungkapkan dalam ranah sikap, hasil penelitian menunjukkan bahwa muridmurid yang diberikan pendekatan STM mempunyai sikap yang lebih positif terhadap pelajaran yang berkarakter logis. Lebih pentingnya lagi adalah penemuan bahwa sikap murid putri terhadap sains dan teknologi meningkat secara dramatis di dalam kelas STM. Diharapkan siswa memiliki pemikiran yang luas tentang perkembangan dan perubahan masyarakat yang diterapkan di masyarakat luas. Dengan STM ini siswa didalam menerima atau menangkap informasi tidak langsung menerima informasi tersebut tetapi siswa mampu menganalisis baik atau buruknya informasi yang diperoleh.

Model STM dalam pembelajaran IPS merupakan pendekatan sinergis aspek sosial, budaya, teknologi dan masyarakat dalam format instruksional. "Isu-isu sosialteknologi di masyarakat merupakan karakteristik kunci dari pendekatan STM" (Yager dalam Lasmawan, 2003:21). Melalui model pembelajaran STM, siswa belajar IPS dalam konteks pengalaman nyata, mengacu pada pertumbuhan yang semakin sempurna (kognitif, sikap dan keterampilan). Melalui STM diharapkan anak dapat diarahkan secara terprogram untuk mencapai penguasaan pengetahuan, keterampilan dan sikap tertentu demi tugas-tugas dimasyarakat.

\section{METODE}

Penelitian ini menggunakan metode eksperimen. Menurut Sukardi (2007:179) metode eksperimen merupakan metode sistematis guna membangun hubungan yang mengandung sebab akibat (Causal-Effect Relationship). Salah satu ciri penting suatu eksperimen adalah pengelompokkan secara 
random, sehingga hubungan kausal yang terjadi memang disebabkan oleh adanya perlakuan, bukan oleh faktor lain (Dantes, 2012: 94). Jenis penelitian ini adalah penelitian eksperimen semu (quasy experiment). Hal ini dikarenakan peneliti tidak mungkin mengubah kelas dalam menentukan subjek atau kelas dalam penelitian ini, sehingga yang dirandom hanya kelas bukan individu di dalam kelas tersebut. Populasi dalam penelitian ini adalah siswa kelas IX SMP Negeri 1 Penebel sebanyak 249 siswa yang terbagi ke dalam 10 kelas. Dalam penelitian ini sampel dipilih tanpa adanya pengacakan individu, cara ini digunakan dengan mengingat dan mempertimbangkan sulitnya untuk merubah kelas yang sudah terbentuk. Kelas - kelas yang terpilih sebagai sampel yang mewakili populasi kemudian di bagi menjadi 2 yaitu kelas eksperimen dan kelas kontrol. Data dikumpulkan dengan tes dan dianalisis dengan anava satu jalur dan manova.

\section{HASIL DAN PEMBAHASAN}

Data yang telah terkumpul dalam penelitian ini ditabulasikan sesuai dengan keperluan analisis data yang tercantum dalam rancangan penelitian yang bertujuan untuk memberikan gambaran umum mengenai penyebaran atau distribusi data. Data hasil pengukuran ditransformasi menjadi skor 100 sesuai yang berlaku di sekolah. Sebagaimana telah dikemukakan bahwa penelitian ini adalah penelitian eksperimen semua dengan analisis uji-anava satu jalur dan manova sehingga berdasarkan rancangan tersebut maka deskripsi data yang akan disajikan pada bagian ini terdiri atas empat kelompok, yaitu (1) prestasi belajar siswa yang mengikuti pembelajaran dengan model pembelajaran STM, (2) kemampuan berpikir kritis siswa yang mengikuti pembelajaran dengan model pembelajaran STM (3) prestasi belajar siswa yang mengikuti pembelajaran dengan model pembelajaran konvensional, dan (4) kemampuan berpikir kritis siswa yang mengikuti pembelajaran dengan model pembelajaran konvensional.

Berdasarkan hasil analisis dengan analisis varians satu jalur diperoleh bahwa nilai $F_{\text {hitung }}=84,437(p=0,000<0,05)$. Oleh karena itu, hipotesis nol (Ho) yang menyatakan bahwa tidak ada perbedaan prestasi belajar siswa antara yang mengikuti pembelajaran dengan model STM dan langsung ditolak. Jadi, ada perbedaan prestasi belajar siswa antara yang mengikuti pembelajaran dengan model STM dan pembelajaran konvensional.

Hasil perhitungan menunjukkan bahwa perbedaan prestasi belajar siswa yang mengikuti pembelajaran dengan STM pada siswa kelas IX SMP Negeri 1 Penebel dengan skor rata-rata 83,781, sedangkan prestasi belajar siswa yang mengikuti pembelajaran dengan pembelajaran konvensional pada siswa kelas IX SMP Negeri 1 Penebel dengan skor rata-rata 74,333 . Ternyata skor rata-rata prestasi belajar siswa yang mengikuti pembelajaran dengan model STM lebih tinggi daripada sikap siswa yang mengikuti pembelajaran dengan pembelajaran konvensional pada siswa kelas kelas IX SMP Negeri 1 Penebel. Dengan demikian, dapat disimpulkan prestasi belajar siswa yang mengikuti pembelajaran dengan model STM lebih tinggi daripada siswa yang mengikuti pembelajaran dengan pembelajaran konvensional pada siswa kelas IX SMP Negeri 1 Penebel.

Dari hasil uji hipotesis tersebut mengisyaratkan bahwa model pembelajaran STM lebih unggul dalam meningkatkan hasil belajar IPS daripada model pembelajaran konvensional. Hal ini disebabkan karena dalam pembelajaran IPS dengan model pembelajaran STM, siswa diarahkan untuk literasi sains dan teknologi. Artinya siswa dapat memahami dari segi sains teknologi, dan lingkungan sekitarnya, yang penuh dengan produk teknologi serta dampakdampak sosial yang ditimbulkannya. Pada dasarnya orang yang memiliki literasi sains dan teknologi, memiliki pemahaman dan kesadaran tentang sains dan teknologi dan tidak sekadar dapat baca dan tulis sains dan teknologi saja. Pemahaman mencakup pemahaman tentang konsep sains dan teknologi, saling keterkaitannya dan dampaknya bagi umat manusia. Adapun kesadaran mencakup unsur sikap dan 
prilaku yang dapat diamati melalui tindakan atau kecenderungan bertindak.

Model pembelajaran STM dapat juga

dikatakan sebagai upaya mendekatkan siswa kepada obyek yang dibahas. Pembelajaran yang menjadikan benda yang dibahas secara langsung diharapkan kepada siswa atau siswa dibawa langsung ke alam sekitarnya, disebut sebagai onstention (Barnes dalam Prayekti, 2001:11). Dalam belajar semacam ini siswa mencari hubungan kesamaan (similarity relation) sehingga memperoleh kelompok berdasarkan konsep dan teori yang telah dimiliki dan memperoleh pola-pola berdasarkan pengamatan. Hal ini sesuai dengan apa yang dikatakan Gagne (dalam Prayekti, 2001:15) bahwa untuk terjadi belajar pada diri siswa diperlukan kondisi belajar, baik kondisi internal maupun eksternal. Kondisi internal merupakan peningkatan (arising) memori siswa sebagai hasil belajar terdahulu. Memori siswa yang terdahulu merupakan komponen kemampuan yang baru, dan ditempatkannya bersama-sama. Kondisi eksternal meliputi aspek atau benda yang dirancang atau ditata dalam suatu pembelajaran yang termasuk di dalamnya adalah lingkungan. Suatu proses belajar mengajar dikatakan dapat berjalan efektif bila seluruh komponen yang berpengaruh dalam proses belajar mengajar saling mendukung dalam rangka mencapai tujuan. Misalnya penyajian materi menarik, adanya sarana belajar yang memadai, dan memiliki tujuan yang jelas serta sesuai dengan pengalaman anak-anak sehari-hari.

Model STM dalam pembelajaran IPS merupakan pendekatan sinergis aspek sosial, budaya, teknologi dan masyarakat dalam format instruksional. "Isu-isu sosialteknologi di masyarakat merupakan karakteristik kunci dari pendekatan STM" (Yager dalam Lasmawan, 2003:21). Melalui model pembelajaran STM, siswa belajar IPS dalam konteks pengalaman nyata, mengacu pada pertumbuhan yang semakin sempurna (kognitif, sikap dan keterampilan). Melalui STM diharapkan anak dapat diarahkan secara terprogram untuk mencapai penguasaan pengetahuan, keterampilan dan sikap tertentu demi tugas-tugas dimasyarakat.

Pembelajaran dengan menggunakan model pembelajaran Sains Teknologi Masyarakat menyajikan isu yang terkait dengan berbagai konsep dan prinsip ilmiah yang sedang dipelajari oleh siswa, dengan demikian, siswa belajar IPS seolah-olah belajar dekat dengan lingkungan sosial. Hal ini menunjukkan bahwa belajar IPS tidak hanya merupakan hapalan saja melainkan kelihatan manfaatnya dalam kehidupan sehari-hari. Kenyataan ini akan mendorong siswa untuk memecahkan masalah-masalah sosial yang terkait dengan permasalahan sehari-hari. Dengan adanya keterkaiatan antara apa yang dipelajari dengan kehidupan sosial akan memotivasi siswa untuk terus belajar sehingga prestasi belajar akan meningkat.

Di lain pihak, pembelajaran konvensional tidak menekankan pada peran aktif siswa dalam membangun pemahaman mereka sendiri tentang pengetahuan yang dipelajarinya, tetapi guru langsung memberikan segala informasi yang dianggap penting oleh guru sehingga siswa akan berperan pasif dalam proses pembelajaran. Jika dilihat dari tiga jalur modus penyampaian informasi pembelajaran, penyelenggaraan pembelajaran konvensional lebih sering menggunakan modus telling (pemberian informasi), ketimbang modus demonstrating (memperagakan) dan doing direct performance (memberikan kesempatan untuk menampilkan unjuk kerja secara langsung) (Juliantara, 2009). Dengan kata lain bahwa guru lebih sering menggunakan strategi atau metode ceramah dengan mengikuti urutan materi dalam kurikulum secara ketat. Guru berasumsi bahwa keberhasilan program pembelajaran dilihat dari ketuntasannya menyampaikan seluruh materi yang ada dalam kurikulum. Pembelajaran seperti mengakibatkan belum optimalnya prestasi belajar siswa.

Keberhasilan penelitan ini juga didukung oleh hasil penelitian yang dilakukan oleh Tristina (2016) dalam tesisnya yang berjudul : "Pengaruh Model Pembelajaran Sains Teknologi Masyarakat (Stm) Terhadap 
Prestasi Belajar IPS Dan Keterampilan Sosial Pada Siswa Kelas V SD Negeri Gugus II Kecamatan Seririt Tahun Pelajaran 2015/2016" adalah sebagai berikut: menunjukkan bahwa model STM memberikan pengaruh yang signifikan terhadap prestasi belajar IPS siswa kelas menunjukkan bahwa model STM memberikan pengaruh yang signifikan terhadap prestasi belajar dan keterampilan sosial IPS siswa kelas V SD Negeri Gugus II kecamatan Seririt tahun pelajaran 2015/2016. Hasil analisis deskriptif yang dilakukan mengenai tes prestasi belajar IPS dengan model pembelajaran SainsTeknologi-Masyarakat dan pembelajaran konvensional menunjukkan bahwa rata-rata skor prestasi belajar IPS siswa dengan model pembelajaran Sains-TeknologiMasyarakat adalah 22,45 dan rata-rata skor prestasi belajar IPS dengan pembelajaran konvensional adalah 18,56.

Hasil penelitian seperti yang disebutkan di atas tampak bahwa model STM berpengaruh terhadap prestasi belajar siswa. Dengan demikian dapat disimpulkan bahwa terdapat perbedaan prestasi belajar siswa antara yang mengikuti pembelajaran dengan model STM dan pembelajarn konvensional pada siswa kelas IX SMP Negeri 1 Penebel terbukti secara teoretis dan empiris.

Berdasarkan hasil analisis dengan analisis varians satu jalur sebagaimana diperoleh nilai $\mathrm{F}_{\text {hitung }}=50,209(\mathrm{p}=0,000<$ $0,05)$. Oleh karena itu, hipotesis nol $(\mathrm{Ho})$ yang menyatakan bahwa tidak perbedaan kemampuan berpikir kritis siswa antara yang mengikuti pembelajaran dengan model STM dan langsung pada siswa kelas IX SMP Negeri 1 Penebel ditolak. Jadi, ada perbedaan kemampuan berpikir kritis siswa antara yang mengikuti pembelajaran dengan model STM dan pembelajaran konvensional pada siswa kelas IX SMP Negeri 1 Penebel.

Hasil perhitungan menunjukkan bahwa kemampuan berpikir kritis siswa yang mengikuti pembelajaran dengan model STM pada siswa kelas IX SMP Negeri 1 Penebel dengan skor rata-rata 80,406 , sedangkan kemampuan berpikir kritis siswa yang mengikuti pembelajaran dengan pembelajaran konvensional pada siswa kelas siswa kelas IX SMP Negeri 1 Penebel dengan skor rata-rata 72,800 . Ternyata skor rata-rata kemampuan berpikir kritis siswa yang mengikuti pembelajaran dengan model STM lebih tinggi daripada kemampuan berpikir kritis siswa yang mengikuti pembelajaran dengan pembelajaran konvensional pada siswa siswa kelas IX SMP Negeri 1 penebel. Dengan demikian, dapat disimpulkan kemampuan berpikir kritis, siswa yang mengikuti pembelajaran dengan model STM lebih tinggi daripada keterampilan siswa yang mengikuti pembelajaran dengan pembelajaran konvensional pada siswa kelas IX SMP Negeri 1 Penebel.

Keberhasilan penelitian ini disebabkan karena model pembelajaran STM dipandang sebagai sebuah pembaharuan dalam pembelajaran IPS pada jenjang sekolah dasar dan menengah hampir diseluruh dunia. Konsepsi ini didasari oleh suatu rasional bahwa dalam aplikasinya, model ini memerlukan pembaharuan pemikiran yang mendasar dan baru di kalangan guru maupun siswa. ilmu pengetahuan dan teknologi merupakan dua hal yang tidak dapat dipisahkan dari kehidupan masyarakat. IImu pengetahuan dan teknologi dapat berkembang dengan cepat karena masyarakat sendiri yang menumbuh kembangkannya. Maka dari itu, ilmu pengetahuan dan teknologi perlu diberikan kepada siswa baik dari tingkat dasar sampai jenjang yang lebih tinggi. Penelitian ini juga didukung oleh pendapat Winecoff (dalam Lasmawan, 2003:7) yang menyatakan bahwa melalui model STM, peserta didik belajar IPS dalam konteks pengalaman nyata, yang meliputi aplikasi keterampilan berpikir, memecahkan masalah, apresiasi budaya, dan keterampilan mengambil keputusan yang akurat terhadap hubungan kausal ilmu pengetahuan, teknologi dan masyarakat.

Model STM dalam pembelajaran IPS dapat membantu peserta didik melatih kemampuan dan keterampilannya memecahkan masalah dan mengambil keputusan yang akurat terhadap masalahmasalah yang tumbuh dan berkembang di 
masyarakat (Yager, 1996:24). Pembelajaran bukan hanya mentransfer ilmu pengetahuan saja, tetapi juga berkaitan dengan bagaimana siswa mampu memahami dampak dari pembelajaran atau hasil pembelajaran tersebut baik dampak positif maupun negatifnya. Dengan adanya penggunaan model STM yang diimplementasikan pada pembelajaran IPS di sekolah menengah, siswa akan memiliki persiapan sedini mungkin dalam menghadapi tantangan di masa depan yang secara kualitatif cenderung meningkat.

Karena dalam

penerapan

pembelajaran konvensional menggunakan metode ceramah, maka cenderung kegiatan pembelajaran yang dilakukan akan berpusat pada guru (teacher centered) dan terjadi komunikasi searah, yaitu dari guru kepada siswa. Guru mendominasi seluruh kegiatan dalam pembelajaran, sedangkan siswa hanya memperhatikan dan membuat catatan seperlunya. Dalam pembelajaran konvensional biasanya memiliki kekhasan tertentu, misalnya lebih mengutamakan hafalan daripada pengertian, menekankan kepada keterampilan berhitung, mengutamakan hasil daripada proses, dan dalam proses pembelajaran siswa cenderung pasif. Dengan demikian pembelajaran seperti ini tidak mendorong siswa berpikir kritis.

Hasil penelitian ini juga didukung oleh penelitian yang dilakukan oleh Ardana (2013) yang berjudul Pengaruh Model Sains Teknologi Masyarakat Terhadap Kemampuan Berpikir Kreatif dan Pemahaman Konsep dalam Pembelajaran IPS Siswa SD di Desa Kalibuduk. Dalam penelitian ini dinyatakan terdapat perbedaan kemampuan berpikir kreatif yang signifikan antara siswa yang mengikuti model pembelajaran STM dengan siswa yang mengkuti model pembelajaran konvensional $(F=21,507 \quad p<0,05)$. Terdapat perbedaan pemahaman konsep IPS yang signifikan antara siswa ynag mengikuti model pembelajaran STM dan siswa mengikuti model pembelajan konvensioanl: $(F=3,756$ dan $p<0,05)$. Secara simultan perbedaan kemmapuan berpikir kreatif dan pemahaman konsep IPS yang signifikan, antara siswa yang mengikuti model pembelajaran STM dan siswa yang memiliki model pembelajaran konvensional $(F=11,917$ dan $p<0,05)$.

Hasil di atas menunjukkan bahwa model STM dapat meningkatkan kemampuan berpikir kritis siswa baik secara teoretik maupun secara empiris. Dengan demikian dapat dinyatakan bahwa ada perbedaan kemampuan berpikir kritis siswa antara yang mengikuti pembelajaran dengan model STM dan pembelajaran konvensional pada siswa kelas IX SMP Negeri 1 Penebel. Jika dilihat dari rata-rata dan kualifikasi kemampuan berpikir kritis, tampak bahwa siswa yang mengikuti pembelajaran dengan model STM memperoleh kemampuan berpikir kritis lebih tinggi dari pada siswa yang mengikuti pembelajaran dengan pembelajaran konvensional pada siswa kelas IX SMP Negeri 1 Penebel.

Berdasarkan hasil analisis dengan manova sebagaimana disajikan pada Tabel 4.7, tampak bahwa nilai F- Wilks' Lambda = $43,569(p=0,000<0,05)$. Oleh karena itu, hipotesis nol ( $\mathrm{Ho})$ yang menyatakan bahwa tidak ada perbedaan prestasi belajar dan kemampuan berpikir kritis siswa secara simultan antara yang mengikuti pembelajaran dengan model STM dan pembelajaran konvensional pada siswa kelas IX SMP Negeri 1 Penebel. Jadi, terdapat perbedaan prestasi belajar dan kemampuan berpikir kritis siswa antara yang mengikuti pembelajaran dengan model STM dan pembelajaran konvensional pada siswa kelas IX SMP Negeri 1 Penebel.

Model STM dalam pembelajaran IPS dapat mengintegrasikan antara pengetahuan, keterampilan, sikap dan nilai hidup manusia dalam konteks pembelajaran formal, baik yang berlangsung di dalam kelas maupun di luar kelas. Oleh karena itu, dalam aplikasinya pendidik tidak semata-mata membelajarkan konsep kepada siswa, namun lebih ditekankan pada pembelajaran keterampilan, sikap dan nilai-nilai kehidupan yang berkaitan dengan IPTEK. Pencapaian terhadap tujuan pembelajaran di atas mengarahkan pembelajaran IPS dengan model STM membelajarkan siswa agar mereka tahu, paham dan terampil menyikapi 
implikasi sosial dan manfaat kemajuan IPTEK berdasarkan pengalamannya seharihari, sehingga mereka menjadi sadar dan mahir menggunakan IPTEK bagi perbaikan dan kebertahanan hidup masyarakatnya. Pembelajaran dengan model STM menjadikan siswa sebagai pusat pembelajaran dimana harus disesuaikan dengan tingkat psikologis siswa dan latar belakang sosial yang mereka jalani seharihari. Materi dan struktur pembelajaran IPS diarahkan pada menemukan isu/masalah di masyarakat yang berkaitan dengan teknologi dan masyarakat, pemahaman konsep, perumusan dan pengujian hipotesis sederhana dan pengambilan keputusan terhadap masalah-masalah IPTEK di masyarakat (Yager, 1996).

Hasil penelitian ini juga didukung oleh penelitian eksperimen yang dilakukan oleh Penelitian yang dilakukan oleh Ardana (2013) yang berjudul Pengaruh Model Sains Teknologi Masyarakat Terhadap Kemampuan Berpikir Kreatif dan Pemahaman Konsep dalam Pembelajaran IPS Siswa SD di Desa Kalibuduk. Dalam penelitian ini dinyatakan terdapat perbedaan kemampuan berpikir kreatif yang signifikan antara siswa yang mengikuti model pembelajaran STM dengan siswa yang mengkuti model pembelajaran konvensional $(F=21,507 \quad p<0,05)$. Terdapat perbedaan pemahaman konsep IPS yang signifikan antara siswa yang mengikuti model pembelajaran STM dan siswa mengikuti model pembelajan konvensioanl: $(F=3,756$ dan $p<0,05)$. Secara simultan perbedaan kemmapuan berpikir kreatif dan pemahaman konsep IPS yang signifikan, antara siswa yang mengikuti model pembelajaran SM dan siswa yang memiliki model pembelajaran konvensional $(F=11,917$ dan $p<0,05)$.

Dengan demikian dapat dinyatakan bahwa ada perbedaan prestasi belajar dan kemampuan berpikir kritis siswa antara yang mengikuti pembelajaran dengan model STM dan model pembelajaran konvensional pada siswa kelas IX SMP Negeri 1 Penebel telah terbukti secara teoretis dan empiris.

\section{SIMPULAN}

Berdasarkan analisis dan pembahasan seperti yang telah dipaparkan pada bagian sebelumnya, maka dapat dirangkum beberapa hal sebagai berikut, terdapat perbedaan prestasi belajar siswa antara yang mengikuti pembelajaran dengan model STM dan konvensional pada siswa kelas IXI SMP Negeri 11 Denpasar dengan $F_{\text {hitung }}=84,437(p=0,000<0,05)$, terdapat perbedaan kemampuan berpikir kritis siswa antara yang mengikuti pembelajaran dengan model STM dan pembelajaran konvensional pada siswa kelas IX SMP Negeri 1 Penebel dengan $F_{\text {hitung }}=50,209(p=0,000<0,05)$, terdapat perbedaan prestasi belajar dan kemampuan berpikir kritis siswa antara yang mengikuti pembelajaran dengan model STM dan pembelajaran konvensional pada siswa kelas IXI SMP Negeri 11 Denpasar dengan F- Wilks' Lambda $=43,569(p=0,000<$ $0,05)$.

dapat disimpulkan bahwa model pembelajaran STM dan model pembelajaran konvensional berpengaruh secara signifikan terhadap prestasi belajar dan kemampuan berpikir kritis siswa kelas IX SMP Negeri 1 Penebel baik secara terpisah maupun simultan. Untuk itu kedua model pembelajarn masih dapat digunakan dalam pembelajaran IPS, namun yang kebih baik adalah model pembelajaran STM.

\section{DAFTAR PUSTAKA}

Ardana, I Wayan. 2013. Pengaruh Model Sains-Teknologi-Masyarakat (STM) Terhadap Kemampuan Berpikir Kreatif dan Pemahaman Konsep Dalam Pembelajaran IPS Siswa SD di Desa Kalibukbuk. E-jurnal Pascasarjana Undiksha Volume 3 Nomor 1.

Arikunto, Suharsimi. 2006. Prosedur Penelitian Suatu Pendekatan Praktik. Jakarta : Rineka Cipta

Banks, J.A. 1977. Teaching Strategies for the Social Studies: Inquiry, Valuing and Decision Making. Massachusett: Addison Wesley Publishing Company.

Sri Evariani | 49 dari 50 
Candiasa, I Made. 2010. Statistik Multivariat Disertai Aplikasi SPSS. Singaraja: Undiksha Press

Daini. 2009. "Pengaruh Model Pembelajaran Sains-Teknologi-Masyarakat (STM) Terhadap Prestasi Belajar dan Literasi Sosial-Teknologi siswa Dalam Pembelajaran IPS pada siswa SMP". Tesis (tidak dipublikasikan) Singaraja: Undiksha.

Filsaime, D.K. 2008. Menguak Rahasia Berpikir Kritis dan Kreatif. Jakarta: Prestasi Pustaka

Suryabrata, S. 2011. Metodologi Penelitian.Jakarta: Rajawali Pers
Suryosubroto,
Belajar
B. 1997. Proses
Sekolah. Jakarta: Rineka Cipta.

$\begin{array}{ccr}\text { Trianto. } & \begin{array}{c}2009 . \\ \text { Pembelajaran }\end{array} \\ \text { Jakarta: Kencana. } & \text { Inovatif-Progresif. } \\ \text { Robert } & \text { E. } & 1996 .\end{array}$

Science/Technology/Society: As

Reform in Science Education. New York: State University of New York Pres 
